DOI: 10.17117/na.2016.02.02.202

http://ucom.ru/doc/na.2016.02.02.202.pdf

Поступила (Received): 28.02.2016

Першина С.B.

Нетрадиционные методы и приемы музыкального

воспитания в работе с дошкольниками

\author{
Pershina S.V. \\ Nontraditional methods and techniques of musical \\ education to work with preschool children
}

Статья посвящена некоторым аспектам в методике музыкального воспитания в работе $c$ детьми дошкольного возраста, в статье идет речь о разнообразных методических приемах, заимствованных извне, и их значении в развитии творческих способностей детей

Ключевые слова: методика, приемы, дошкольный возраст

\section{Першина Светлана Викторовна}

Музыкальный руководитель

Детский сад комбинированного вида №11

г. Белгород, ул. Некрасова, 14 A

\begin{abstract}
The article is devoted to some aspects of the method of musical education in work with children of preschool age, the article deals with a variety of teaching methods borrowed from the outside, and their importance in the development of creative abilities of children
\end{abstract}

Key words: technique, method, preschool age

\author{
Pershina Svetlana Viktorovna \\ Musical Director \\ Kindergarten combined type №11 \\ Belgorod, Nekrasova st., $14 \mathrm{~A}$
}

Развитие ребенка осуществляется в условиях взаимодействия его индивидуальных особенностей с теми условиями, в которых он живет. Задача взрослых, как можно раньше создать благоприятные условия для их развития.

При педагогическом воздействии на формирование психических функций особое внимание необходимо уделять развитию эмоций, восприятий и представлений. Эмоции способствуют раскрытию творческих способностей, сопровождают все виды музыкальной деятельности.

Большое значение в развитии эмоциональности занимают несложные музыкальные этюды. Этюды можно рассматривать как небольшие сюжетные и несюжетные игры творческого характера. Исполняя этюды, дети учатся точно соотносить определенные движения, мимику с настроением, характером персонажа, заданного в музыкальном произведении. Этюд - это набросок, импровизация. Невольно возникает вопрос: «Возможно ли повторение?» Будет ли этюд соответствовать своему смыслу? Да будет. Повторение этюдов дает детям возможность углубить ранее созданный образ, выразительнее, эмоциональнее исполнить детали.

Раскрытию эмоционального потенциала ребенка способствует методика Е.В. Горшковой «От жеста к танцу». По движениям, по осанке человека можно 
судить о его эмоциональном состоянии, даже о личностных свойствах. Эти содержательные свойства движений сохранились и в танце.

Это обусловлено сочетанием в единой деятельности музыки, движения и игры (драматизации) - каждая из составляющих способствует развитию у детей творчества, воображения, эмоциональности. Принципиальная особенность данной методики заключается в том, что работа над эмоциональностью, выразительностью исполнения начинается не после, а до того, как дети полностью овладеют двигательным навыком.

Дети познают жизнь, музыку как одну из сторон жизни. Австрийский композитор Карл Орф видит в ребенке не гостя, а соавтора и создателя собственного музыкального мира. Обучение в действии - так можно определить одну из главных идей концепции Карла Орфа. Интерес к музыке способствует раскрытию призвания и развитию различных способностей ребенка. А побудить этот интерес помогает система Карла Орфа.

Применение речи в обучении музыки - один из важнейших принципов педагогики К. Орфа. Для музыкального воспитания речевые упражнения важны прежде всего потому что музыкальный слух развивается в тесной, связи со слухом речевым. Речевой слух - одна из основ слуха музыкального. Ребенок учится пользоваться выразительными средствами, общими для речи и музыки: темы, ритм, регистр, артикуляция, динамика, фразировка.

Речевые упражнения как основа первоначальной музыкальной тренировки - одна из очень удачных находок Орфа. Педагогическая идея - оттолкнуться при изучении музыкального ритма от ритма слов. Ритм, заключенный в словах, фразах, ощущается детьми естественно и извлекается без всякого труда: прохлопывается, переносится на шумовые инструменты.

Речевые упражнения служат эффективным средством интонационного слуха, средством постижения строения музыкальной формы, наиболее доступное средство для развития предпосылок умения импровизировать.

Инструментальное сопровождение речевых упражнений дает дополнительные богатые возможности для развития интерпретаций: «звучащие жесты», шумовые ударные, звуковысотные инструменты. К.Орф считал, что детей нужно учить играть не на сложных, а на простых инструментах: ударных, треугольнике, маракасах, колокольчиках, металлофонах.

Музыка и движение образуют неразделимое единство в концепции Орфа. Развитие навыков движения рассматривается Орфом не как самоцель, а как одно из средств музыкального и эмоционального совершенствования.

Движение - основа формирования чувства ритма, которое имеет в своей основе моторную природу и всегда сопровождается моторными реакциями. Восприятие ритма вызывает многообразие двигательных ощущений: сокращение языка, мышц головы, пальцев ног, гортани, грудной клетки и др.

Широко используются в речевых упражнениях игра чисто звуковыми элементами речи (фонемами, слогами) артикуляционная игра, игра голоса. Игры способствуют развитию фонематического, тембрового и звуковысотного компонентов музыкального слуха, а также является ценными фонопедическими 
упражнениями, подготавливающими детей к пению. В.В. Емельянов лечил голоса и придумал свою методику - фонопедию: упражнения, предназначенные для решения только координационных (между звуком и голосом) и тренировочных задач. Упражнения узко направлены, вспомогательны по отношению к вокальной педагогике, сформированы в отрасли восстановительной медицинской педагогики.

Цель метода Емельянова - развитие голоса каждого ребенка со своими особенностями и способностями, с чем и приходиться сталкиваться музыкальному руководителю в детском саду. Этот метод включает артикуляционную гимнастику, интонационно-фонетические упражнения, голосовые сигналы доречевой коммуникации, фонопедические приемы в нефальцетном режиме. Все эти упражнения помогают поддерживать интерес у детей на занятиях к определенному виду деятельности.

Пение является наиболее доступным видом исполнительства в музыкальной деятельности. Доминирующая роль пения в формировании у детей музыкальных способностей является основой для более детальной разработки методов музыкального воспитания.

Эффективен прием, мобилизующий детское внимание, «пение про себя», когда по знаку педагога часть ранее выученного музыкального произведения исполняется как обычно, а часть - молча, пропевая только внутренним слухом. Сигналом к ведению пения «про себя» служит мимика музыкального руководителя.

Всегда дает положительные результаты вокальное воспроизведение детьми лейтмотивов инструментальных пьес. Мелодия в данном случае лучше записывается, становится легко узнаваемой и помогает сильнее прочувствовать настроение пьесы. Дети с желанием вокализируют пьесы. Текст с успехом выполняет частную функцию - помогает запомнить прослушанную пьесу и подольше удержать в сознании ее лейттемы.

Словесное оформление впечатления о музыкальном произведении улучшает усвоение музыки, развивает осознанность этого процесса, углубляет его эмоциональную окраску. С детьми старшего дошкольного возраста можно использовать вариант «копилки», построенный на разработанном Ш. Амонашвили приеме анализа слова. Педагог дает характеристику музыкального произведения. Задача детей «поймать» определение, данное педагогом в собственные ладони, сложенные «чашечкой», а затем после секундного обдумывания подтвердить его или опровергнуть. В процессе такой игры можно расширять словарный запас детей, эпитетный ряд.

Хорошо известно, что заинтересованность облегчает и стимулирует развитие. Чтобы она появилась у ребенка педагогу нужно постоянно быть в поиске дидактических находок, способных заинтересовать дошкольника, разнообразить обучение новыми методическими изюминки.

Педагог для этого должен искать способы максимального включения ребенка в активное действие с музыкой, свежие, нестандартные приемы, подходы к вопросам музыкального воспитания. 


\section{Список используемых источников:}

1. Амонашвили Ш.А. Здравствуйте, дети. М. 1983.

2. Тютюнникова Т.Э. Учусь творить. Элементарное музицирование: музыка, речь, движение. М. 2004.

3. Горшкова Е.В. От жеста к танцу. М.: Гном Д, 2002.

4. Черенкова Е. Развивающие игры с пальчиками. М. 2007.

5. Михайлова М.А. Развитие музыкальных способностей детей. Ярославль: Академия развития, 1997.

6. Емельянов В.В. Развитие голоса. СПб.: Лань, 2010.

(C) 2016, Першина С.B.

Нетрадиционные методы и приемы музыкального воспитания в работе с дошкольниками
(C) 2016, Pershina S.V.

Nontraditional methods and techniques of musical education to work with preschool children 